\section{BACTERIA}

\section{The Hot Life}

from our Microbiology Correspondent

THE biochemistry of microorganisms able to grow at high temperatures has fascinated biologists for a long time, and the discovery that some bacteria can grow in boiling water (T. D. Brock et al., J. Bact., 107, 303; 1971) is certain to redouble interest in this area of thermobiology. Brock and his colleagues have been studying for several years the microbiology of thermal springs in Yellowstone National Park and their recent work has centred on Boulder Spring which is fed by two superheated sources. An understanding of the bacteriology of the effluent channel is now beginning to emerge, this particular habitat has a temperature of about $91^{\circ} \mathrm{C}$ which, at the altitude of Yellowstone, means boiling water.

The bacteria which colonize these inhospitable waters are unknown and have not been cultured in the laboratory, but the elegant techniques which Brock has developed for investigations in situ have enabled many of the physiological properties of these organisms to be defined. Brock et al. have found, for example, that the generation times of the bacteria last for 3 to $7.5 \mathrm{~h}$ at temperatures exceeding $90^{\circ}$ C. But their latest study reveals the significant fact that these temperatures are only slightly higher than the optimal temperatures for these organisms.

The technique for determining the environmental optima is very simple. Glass cover slips were suspended in the effluent stream until the colonizing bacteria had formed a dense covering and then the incorporation of various labelled organic substrates was followed in tightly closed vials. The amount of isotope uptake paralleled the amount of bacterial biomass but only occurred if sulphide, or some alternative reduced sulphur compound, was present. The optimal effect was produced with a sulphide level of $13 \mu \mathrm{g}$ per ml., and although this concentration increased the uptake of all compounds tested, the most dramatic stimulation occurred with leucine, acetate and thymidine (Boulder Spring water itself contains about $3 \mu \mathrm{g}$ sulphide per ml.). Brock et al. conclude that these bacteria can utilize sulphides, sulphite and metabisulphite as energy sources and resemble bacteria like Beggiatoa which can incorporate organic matter when reduced sulphur is available. The temperature optimum for isotope uptake stimulated by sulphide ranged from $80^{\circ}$ to $90^{\circ} \mathrm{C}$, irrespective of the organic substrate, and significant incorporation even occurred at the higher temperature of the stream, $91.5^{\circ} \mathrm{C}$.

At least two types of Gram negative bacteria were observed to colonize the cover slips and these could be distinguished by their filamentous or bacillary morphologies. But are the physiological data representative of both bacteria? Autoradiography was unfortunately unable to provide the answer because of the interaction of the sulphide with the photographic emulsion. Although attempts to cultivate these organisms have failed so far, success in this endeavour will be essential to elucidate their peculiar capacity of being able to adapt to boiling water.

\section{ICHTHYOLOGY \\ Red Seu Migrants}

from our Marine Vertebrate Correspondent Although the Suez Canal is blocked to shipping it is still open as a passageway for fish. Two more Red Sea fishes have been discovered recently on the Israeli Mediterranean coast (A. Lourie and A. Ben-Tuvia, Israel J. Zool., 19, $203 ;$ 1970). One of them, Pelates quadrilineatus, is a small, longitudinally striped fish which is found in the coastal waters of the Indo-Pacific region from southern Africa to Australia. It has long been known from the Red Sea but no reports of its occurrence in the Suez Canal are known. This contrasts with the history of the second species, Crenidens crenidens, a sea bream which is common in the Red Sea and was reported as early as 1902 , within 30 years of the cutting of the canal, as one of the most common fishes in the canal and in the Bitter Lakes, and had reached as far as Port Said. Lourie and BenTuvia, who work at the Sea Fisheries Research Station, Haifa, collected in February 1970 many specimens of C. crenidens, up to $15 \mathrm{~cm}$ in body length, in a shallow hypersaline lagoon on the northern coast of Sinai.

Other Red Sea immigrants to the Mediterranean have not proved to have such limited habitats and several of the species are common enough to appear regularly in the commercial fish catches of Israel, the Lebanon and Egypt. According to a recent check list of the Mediterranean fishes of Israel (Israel J Zool., 20, 1; 1971) by Ben-Tuvia, as many as thirty of the 284 species are immigrants from the Red Sea. The fish fauna of the eastern basin totals only a little more than half of the total of 540 Mediterranean species known, and although this is partly the result of the comparative sparsity of field work and study of critical areas, it is clear that it is a relatively impoverished fauna. Fishes of Red Sea origin have perhaps gained a place in the eastern basin more

\title{
RNA.DNA Complexes and Antibody Production
}

SyNTHETIC hybrid nucleic acids containing DNA and RNA chains are familiar tools of biochemists investigating the properties of various nucleic acid polymerases, and measuring the extent to which natural RNAs hybridize with DNA is a technique widely used by molecular biologists probing gene expression in one cell system or another. But complexes between RNA and DNA which occur naturally in cells have seldom been identified, and for that reason alone the experiments reported by Koros, Koster and Mowery in next Wednesday's Nature New Biology will attract considerable interest.

Koros and his colleagues have been investigating the spleen cells of mice, immunized with sheep erythrocytes, which are capable of producing IgM antibodies against sheep red cells and can be assayed in vitro by their ability to lyse these erythrocytes. Using an autoradiographic technique they have followed the incorporation by these cells of pulses of ${ }^{3} \mathrm{H}$-thymidine of ${ }^{3} \mathrm{H}$ 5-uridine. As anticipated, the thymidine label is incorporated into material which can be completely digested by deoxyribonuclease and is therefore almost certainly DNA.

The uridine incorporated by these antibody forming cells, by contrast, re- sponds to digestion by deoxy and ribonucleases in an unusual way. Little if any of the label is removed from the cells by deoxyribonuclease which indicates that little of the uridine can have been converted by the cells to the DNA precursor deoxycytidine. But only about half of the incorporated uridine is digested by ribonuclease, and half the label survives this procedure. If, however, the cells are first digested with deoxyribonuclease and then with ribonuclease all the labelled uridine is digested.

Koros et al. believe that these results indicate that in antibody forming spleen cells much of the RNA which is being made remains somehow complexed with DNA and is thereby protected from ribonuclease digestion until, of course, the DNA is digested. Furthermore, they report that spleen cells which are not making antibody incorporate uridine into RNA, 98 per cent of which can be digested by ribonuclease alone. This result, they claim, shows that RNA. DNA complexes are far more abundant in cells making antibody than in similar cells which have not been stimulated to antibody production. As they point out, these DNA.RNA complexes may be involved in antibody synthesis, acting perhaps as messengers, and they are now trying to test this fascinating idea. 